\title{
TREATMENT RESULTS OF SPINAL CORD INJURIES IN THE SWISS PARAPLEGIC CENTRE OF BASLE
}

\author{
By G. A. Z̈̈сH, M.D., W. Seiler, M.D. and P. Dollfus, M.D. \\ Swiss Paraplegic Centre of Basle, Switzerland
}

WE would like to report on the activities of the Swiss Paraplegic Centre of Basle during the last two years from I June I973 to I June I975. I966.

The organisation of the centre has already been described by Michaelis in

The centre has 80 beds, including a special resuscitation ward, and there is a close medical and surgical cooperation with the University of Basle. We have managed to transport most of the patients directly from the site of the injury to the centre by helicopter, thanks to the Swiss Air Rescue System directed by Dr Bühler. Sometimes in difficult cases one of us accompanies the patient. The first-aid and emergency handling of these patients has been drastically improved in the past years and has already been described by Hachen in 1974.

Four hundred and fourteen patients have been treated during the past two years, of which II 7 post-traumatic patients have been admitted in the acute stage after injury (Table I).

Thirty-one patients have also been admitted after onset but were not of traumatic origin.

We would like to outline in Figure $I$ the large number of acute post-traumatic injuries admitted within the first hours: namely 39 per cent or 45 patients arrived within 12 hours and another 20 per cent or 24 patients within 48 hours.

Where the distribution of sex and age is concerned (fig. 2) we would like to emphasise the large number of young people between 15 and 25 years mainly because of traffic accidents, the second largest group being those admitted between 35 and 45 years mainly because of industrial accidents. We may notice as well the classical incidence of a third being female patients.

Table II gives a summary of the main causes of injuries: 39 per cent were traffic accidents of which roughly one-third were car drivers, one-third passengers and one-third motorcyclists. We can also see the high incidence of industrial

\section{TABLE I}

Admission of patients from June 1973 to June 1975

(Swiss Paraplegic Centre in Basle)

Acute post-traumatic lesions

Death in acute post-traumatic stage

Acute non-traumatic lesions

Check-ups + complications

Total number of admissions 


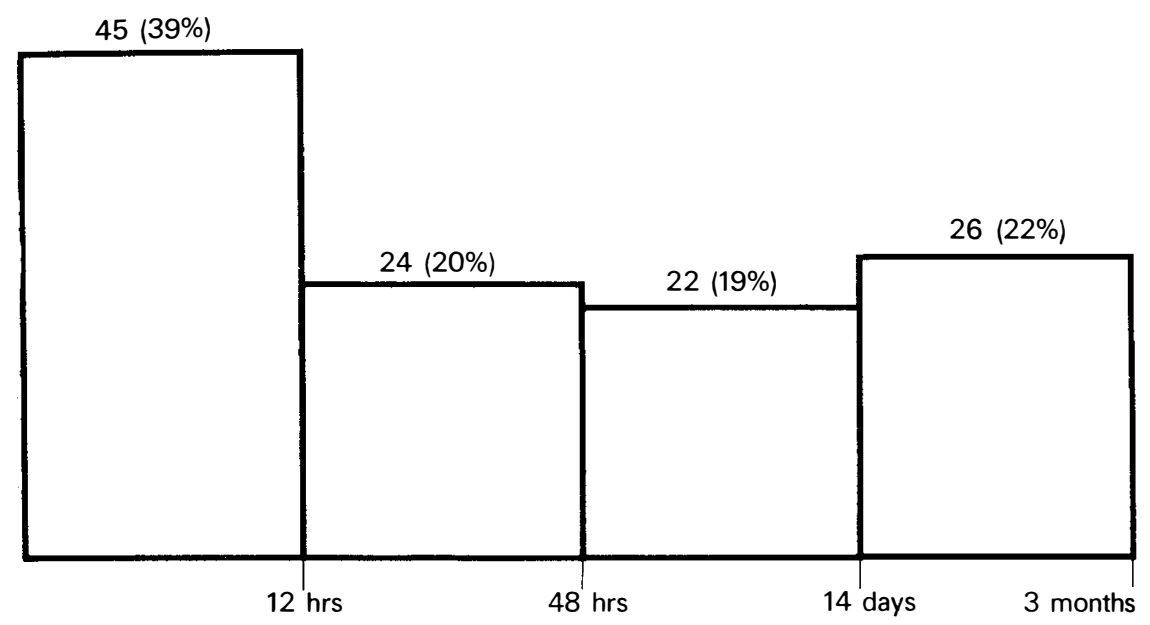

FIG. I

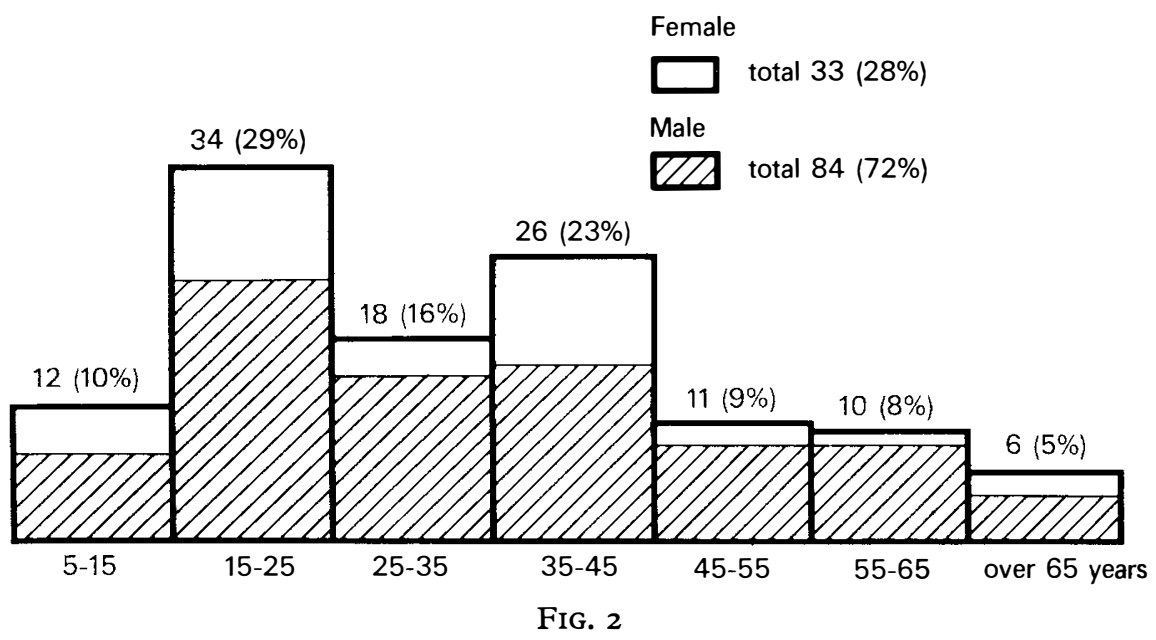

and home accidents: 18 per cent were sport accidents and 9 per cent attempted suicide.

Our treatment of the vertebral injury is mainly conservative (Table III) and in cervical lesions traction by Crutchfield tongs is instituted if needed. The great majority of open reductions and stabilisations were performed before transfer to our centre.

In the last two years we have adopted a more medical attitude in the treatment of spinal cord injury itself, based on the recent results of research in neurophysiopathology occurring immediately and within the first hours after trauma in animal experimentation (Peterson et al., 1965; Ducker \& Hamit, 1969; Hedeman \& Sil, I974; Lewin et al., I974; de la Torre et al., 1974; Osterholm, I974; Campbell et al., I974; Eidelberg et al., I975; Yeo et al., 1975). 
TABLE II

Cause of injury

Traffic accidents $(39 \%)$

\begin{tabular}{|c|c|c|}
\hline Car-Driver & I3 & $(\mathrm{II} \%)$ \\
\hline Passenger & 15 & $(13 \%)$ \\
\hline Motorcycle-Driver & 15 & $(13 \%)$ \\
\hline Passenger & 0 & $(0 \%)$ \\
\hline Bicycle & I & $(1 \%)$ \\
\hline Pedestrian & I & $(1 \%)$ \\
\hline Industrial + Home injuries & 4I & $(34 \%)$ \\
\hline Sport & $2 \mathrm{I}$ & $(18 \%)$ \\
\hline Suicide attempts & IO & $(9 \%)$ \\
\hline Total & II7 & $(100 \%)$ \\
\hline
\end{tabular}

TABLE III

Treatment of vertebral injury

Postural reduction

Laminectomies

Open reductions + Stabilisation

Laminectomies + Reduction + Stabilisation

Total

IOO

4 (3)

7 (4)

6 (5)

I 7

( $)$ = Operation before admission to our centre.

TABLE IV

Medical treatment

Dexamethasone

Rheomacrodex $40^{\circledR}$

Mannitol 20\%

Hydergine ${ }^{\circledR}$

Heparin

Liquamar $^{\circledR}$ $\frac{1}{2} \mathrm{mg} / \mathrm{kg} 4$ days, reduced after until Ioth day $500 \mathrm{ml}$ daily for I week

In special cases only

$0.33 \mathrm{mg}$ every 8 hours for 3 months 5000 i.u. every 12 hours s.c. for 3 weeks After 3 weeks

\section{TABLE V}

Complications in the acute stage

Death within 3 weeks

Cause

Total 5 cases: I C5 Complete, 58 years old

I $\mathrm{T}_{7}$ Complete, 78 years old

Cardiac insufficiency

I C6 Complete, 73 years old

Pneumonia

I $\mathrm{C}_{7}$ Complete, 48 years old (Admission 2 weeks after injury)

I C6 Complete, 58 years old Haematomyelia

Gastro-intestinal bleeding

Total 5 cases: Treatment conservative 3 cases Operation 
The relation between haemorrhagic shock and its direct effect on the nervous system must also be considered in the early treatment of spinal cord injury (Peterson et al., 1965). We have instituted the following routine treatment (Table IV) which can be altered if needed according to the clinical evolution:

(a) Dexamethasone is given at a dosage of $\frac{1}{2} \mathrm{mg} / \mathrm{kg}$ for four days and reduced thereafter until the tenth day. Apart from its classical anti-edema action it might, in the light of recent experimentation (Lewin et al., I974; Eidelberg et al., 1975) have a role in preventing an increased potassium outflux from the injured spinal cord cells. The very early timing of this specific treatment is important, as demonstrated by Ducker and Hamit (1969), Lewin et al. (1974) and Campbell et al. (1974).

Side-effects are watched for very closely, especially as regards the possibility of a gastro-intestinal bleeding, electrolyte disturbances, occasional glucosuria, eventually psychiatric disturbances.

(b) Rheomacrodex $40^{\circledR}: 500 \mathrm{ml} /$ day for one week. Its administration not only corrects hypovolemia but also appears to improve the microcirculation and perhaps that of the injured spinal cord (Goodman \& Gilman, I97I; Fairholm \& Turnbull, I97I; Dohrmann et al., 197I; Fried \& Goodkin, I97I). This effect is a result of the anti-sludge action of Rheomacrodex $40^{\circledR}$ independently of the simple volume expansion. Central venous pressure is routinely checked in all our patients during the acute stage.

(c) Mannitol 20 per cent: $250 \mathrm{ml} /$ day in special cases, for instance: a low diuresis.

(d) Hydergine ${ }^{\circledR}$ : an Ergot Alkaloid Preparation, is given 20 drops $(0.33 \mathrm{mg}$ ) every eight hours for three months. Its action seems to improve the metabolism of the astrocytes and as a direct consequence the microcirculation of the nervous tissues (Herzfeld et al., I972; Sandoz Publication, 1973).

(e) Heparin: 5000 i.u. subcutaneous seems to be the safest way of prevention of thrombosis and pulmonary embolism (Dollfus, I97I; Hachen, I974).

(f) Liquamar $^{\circledR}$ is given as an anticoagulant after three months until mobilisation.

\section{Complications}

Five deaths, all within three weeks after injury, have been excluded from this study (Table V). Two cases could be related as a direct consequence to the spinal cord injury: one pulmonary embolism and one ascending hematomyelia. Five cases of gastro-intestinal bleeding could be in relation to the use of corticoid therapy. Two of them have been treated surgically.

\section{Results}

We would like to give the distribution of the clinical neurological evolution of our cases classified according to the method used by Frankel and others (1969) as seen in Table VI, the first letter of the code being the neurological status on arrival and the second letter the neurological status on discharge. These results are based only on a seriously repeated clinical examination as we do not yet have any personal experience of the modern neuro-physiological sophisticated methods which are still experimentally tried out such as sensory evoked potentials in humans (Perot, I973) and animals (Illingworth \& Molina-Negro, I974). 


\section{TABLE VI}

$\mathrm{A}=$ 'Complete'. This means that the lesion was found to be complete both motor and sensory below the segmental level marked. If there was an alteration of level but the lesion remained complete below the new level, then the arrow would point up or down the 'complete' column.

B = 'Sensory Only'. This implies that there was some sensation present below the level of the lesion but that the motor paralysis was complete below that level. This column does not apply when there is a slight discrepancy between the motor and sensory level but does apply to sacral sparing.

$\mathrm{C}=$ 'Motor Useless'. This implies that there was some motor power present below the lesion but it was of no practical use to the patient.

$\mathrm{D}=$ 'Motor Useful'. This implies that there was useful motor power present below the level of the lesion. Patients in this group could move the lower limbs and many could walk, with or without aids.

$\mathrm{E}=$ 'Recovery'. This implies that the patient was free of neurological symptoms, i.e. no weakness, no sensory loss, no sphincter disturbance. Abnormal reflexes may have been present.

From Frankel, H. L., Hancock, D. O., Hyslop, G. et al. (I969). The value of postural reduction in the initial management of closed injuries of the spine with paraplegia and tetraplegia. Paraplegia, 7, I79-192.

Out of 50 cervical lesions (Table VII) we can notice the relatively small number of 19 initially complete lesions but also the high incidence of improvement, namely eight passing from complete to incomplete lesions.

In the dorsal group (Table VIII) the position is reversed: 22 patients out of 26 initially complete remaining so.

In the TII to LI group (Table IX) only one patient in the five complete on the arrival improved. But we can notice the fairly good results in the incomplete group.

In the L2 to L5 group (Table X), except for one remaining complete, the nine others showed quite a good overall recovery.

Figure 3 shows the relation of recovery in comparison with the time of admission after injury. This we find is the most interesting figure:

(a) Out of the 45-patient group who arrived within I2 hours after injuryalthough including a high number of complete thoracic lesions which usually rarely recover-we can notice a 67 per cent overall recovery.

(b) Admissions between I2 hours and 48 hours only 59 per cent showed overall improvement.

(c) Within the group of patients admitted later than 48 hours we had the highest rate of cervical lesions, but the overall improvement was only 50 per cent.

\section{Conclusions}

Although this is only a preliminary report it shows in fact how important early transport to and treatment in a specialised centre can be, confirming Sir Ludwig Guttmann's teaching (1964, 1973). We believe that our results are encouraging and that there is a definite place in the future for an immediate medical specific treatment of the spinal cord injury itself to which we should pay more attention. 
PAPERS READ AT THE ANNUAL SCIENTIFIC MEETING, I975

TABLE VII: Cervical injuries

TABLE VIII: TI-Tio injuries

\begin{tabular}{|c|c|c|c|c|}
\hline $\begin{array}{c}\mathrm{AA} \\
\mathrm{II}\end{array}$ & $\begin{array}{c}\mathrm{AB} \\
5\end{array}$ & $\begin{array}{c}\mathrm{AC} \\
2\end{array}$ & $\begin{array}{c}\mathrm{AD} \\
\mathrm{I}\end{array}$ & $\begin{array}{c}\mathrm{AE} \\
0\end{array}$ \\
\hline $\begin{array}{c}\mathrm{BA} \\
\mathrm{O}\end{array}$ & $\begin{array}{c}\mathrm{BB} \\
\mathrm{I}\end{array}$ & $\begin{array}{c}\mathrm{BC} \\
2\end{array}$ & $\begin{array}{c}\mathrm{BD} \\
2\end{array}$ & $\begin{array}{c}\mathrm{BE} \\
2\end{array}$ \\
\hline $\begin{array}{c}\mathrm{CA} \\
\mathrm{C}\end{array}$ & $\begin{array}{c}\mathrm{CB} \\
0\end{array}$ & $\begin{array}{c}\mathrm{CC} \\
0\end{array}$ & $\begin{array}{c}\mathrm{CD} \\
8\end{array}$ & $\begin{array}{c}\mathrm{CE} \\
4\end{array}$ \\
\hline $\begin{array}{c}\mathrm{DA} \\
\mathrm{O}\end{array}$ & $\begin{array}{c}\mathrm{DB} \\
0\end{array}$ & $\begin{array}{c}\mathrm{DC} \\
\mathrm{O}\end{array}$ & $\begin{array}{c}\mathrm{DD} \\
2\end{array}$ & $\begin{array}{c}\mathrm{DE} \\
5\end{array}$ \\
\hline $\begin{array}{c}\mathrm{EA} \\
\mathrm{O}\end{array}$ & $\begin{array}{c}\mathrm{EB} \\
0\end{array}$ & $\begin{array}{c}\mathrm{EC} \\
0\end{array}$ & $\begin{array}{c}\mathrm{ED} \\
0\end{array}$ & $\begin{array}{c}\mathrm{EE} \\
5\end{array}$ \\
\hline
\end{tabular}

No change

$$
\begin{array}{cc}
19 & 38 \% \\
31 & 62 \% \\
0 & 0 \\
\hline 50 & 100 \%
\end{array}
$$

\begin{tabular}{|c|c|c|c|c|}
\hline $\begin{array}{c}\text { AA } \\
22\end{array}$ & $\begin{array}{c}\mathrm{AB} \\
\mathrm{I}\end{array}$ & $\begin{array}{c}\mathrm{AC} \\
\mathrm{I}\end{array}$ & $\begin{array}{c}\mathrm{AD} \\
0\end{array}$ & $\underset{2}{\mathrm{AE}}$ \\
\hline $\begin{array}{r}\text { BA } \\
0\end{array}$ & $\begin{array}{c}\mathrm{BB} \\
0\end{array}$ & $\begin{array}{c}\text { BC } \\
\mathbf{2}\end{array}$ & $\begin{array}{c}\mathrm{BD} \\
\mathbf{2}\end{array}$ & $\begin{array}{c}\mathrm{BE} \\
2\end{array}$ \\
\hline $\begin{array}{c}\text { CA } \\
0\end{array}$ & $\begin{array}{c}\mathrm{CB} \\
0\end{array}$ & $\begin{array}{c}\text { CC } \\
0\end{array}$ & $\begin{array}{c}\mathrm{CD} \\
\mathbf{2}\end{array}$ & $\underset{2}{\mathrm{CE}}$ \\
\hline $\begin{array}{c}\text { DA } \\
0\end{array}$ & $\begin{array}{c}\mathrm{DB} \\
0\end{array}$ & $\begin{array}{c}\mathrm{DC} \\
0\end{array}$ & $\begin{array}{c}\mathrm{DD} \\
0\end{array}$ & $\begin{array}{c}\mathrm{DE} \\
0\end{array}$ \\
\hline $\begin{array}{c}\text { EA } \\
0\end{array}$ & $\begin{array}{c}\mathrm{EB} \\
0\end{array}$ & $\begin{array}{c}\mathrm{EC} \\
\mathrm{o}\end{array}$ & $\begin{array}{c}\text { ED } \\
0\end{array}$ & $\begin{array}{c}\mathrm{EE} \\
\mathrm{I}\end{array}$ \\
\hline
\end{tabular}

Improved

No change

$\begin{array}{lrr}\text { Improved } & \text { I } 4 & 38 \% \\ \text { Worsened } & 0 & 0 \%\end{array}$

$$
\begin{array}{rr}
23 & 62 \% \\
14 & 38 \% \\
0 & 0 \% \\
\hline 37 & 100 \%
\end{array}
$$

\begin{tabular}{|c|c|c|c|c|c|c|c|c|c|}
\hline $\begin{array}{c}\mathrm{AA} \\
4\end{array}$ & $\begin{array}{c}\mathrm{AB} \\
0\end{array}$ & $\begin{array}{c}\mathrm{AC} \\
0\end{array}$ & $\underset{\text { I }}{\mathrm{AD}}$ & $\begin{array}{c}\mathrm{AE} \\
0\end{array}$ & $\begin{array}{c}\text { AA } \\
\text { I }\end{array}$ & $\begin{array}{c}\mathrm{AB} \\
0\end{array}$ & $\begin{array}{c}\mathrm{AC} \\
0\end{array}$ & $\begin{array}{c}\mathrm{AD} \\
0\end{array}$ & $\begin{array}{c}\mathrm{AE} \\
0\end{array}$ \\
\hline $\begin{array}{c}\text { BA } \\
0\end{array}$ & $\begin{array}{c}\text { BB } \\
0\end{array}$ & $\begin{array}{c}\mathrm{BC} \\
0\end{array}$ & $\begin{array}{c}\mathrm{BD} \\
4\end{array}$ & $\begin{array}{c}\mathrm{BE} \\
\mathrm{O}\end{array}$ & $\begin{array}{c}\text { BA } \\
0\end{array}$ & $\begin{array}{c}\text { BB } \\
0\end{array}$ & $\begin{array}{c}\text { BC } \\
0\end{array}$ & $\begin{array}{c}\text { BD } \\
2\end{array}$ & $\begin{array}{c}\mathrm{BE} \\
0\end{array}$ \\
\hline $\begin{array}{c}\text { CA } \\
0\end{array}$ & $\begin{array}{c}\mathrm{CB} \\
0\end{array}$ & $\begin{array}{c}\mathrm{CC} \\
\mathrm{O}\end{array}$ & $\begin{array}{c}\text { CD } \\
6\end{array}$ & $\begin{array}{c}\text { CE } \\
\text { I }\end{array}$ & $\begin{array}{c}\text { CA } \\
0\end{array}$ & $\begin{array}{c}\mathrm{CB} \\
\mathrm{O}\end{array}$ & $\begin{array}{c}\mathrm{CC} \\
\mathrm{O}\end{array}$ & $\begin{array}{c}\text { CD } \\
3\end{array}$ & $\begin{array}{c}\mathrm{CE} \\
\mathrm{I}\end{array}$ \\
\hline $\begin{array}{c}\text { DA } \\
0\end{array}$ & $\begin{array}{c}\mathrm{DB} \\
0\end{array}$ & $\begin{array}{c}\mathrm{DC} \\
0\end{array}$ & $\begin{array}{c}\text { DD } \\
\text { I }\end{array}$ & $\begin{array}{c}\mathrm{DE} \\
2\end{array}$ & $\begin{array}{c}\text { DA } \\
0\end{array}$ & $\begin{array}{c}\text { DB } \\
0\end{array}$ & $\begin{array}{c}\text { DC } \\
0\end{array}$ & $\begin{array}{c}\text { DD } \\
0\end{array}$ & $\begin{array}{c}\mathrm{DE} \\
3\end{array}$ \\
\hline $\begin{array}{c}\mathrm{EA} \\
0\end{array}$ & $\begin{array}{c}\text { EB } \\
0\end{array}$ & $\begin{array}{c}\text { EC } \\
\circ\end{array}$ & $\begin{array}{c}\text { ED } \\
0\end{array}$ & $\begin{array}{c}\mathrm{EE} \\
\text { I }\end{array}$ & $\begin{array}{c}\text { EA } \\
0\end{array}$ & $\begin{array}{c}\text { EB } \\
0\end{array}$ & $\begin{array}{c}\text { EC } \\
\circ\end{array}$ & $\begin{array}{c}\text { ED } \\
0\end{array}$ & $\begin{array}{c}\mathrm{EE} \\
\mathrm{O}\end{array}$ \\
\hline & $\begin{array}{l}\text { No change } \\
\text { Improved } \\
\text { Worsened }\end{array}$ & $\begin{array}{r}6 \\
14 \\
0 \\
20\end{array}$ & $\begin{array}{r}30 \% \\
70 \% \\
0 \% \\
100 \%\end{array}$ & & & $\begin{array}{l}\text { No chan } \\
\text { Improve } \\
\text { Worsene }\end{array}$ & $\begin{array}{l}\text { I } \\
9 \\
0 \\
\\
10\end{array}$ & $\begin{array}{l}10 \% \\
90 \% \\
0 \% \\
100 \%\end{array}$ & \\
\hline
\end{tabular}

TABLE IX: TII-LI injuries

TABLE X: L2-L5 injuries 


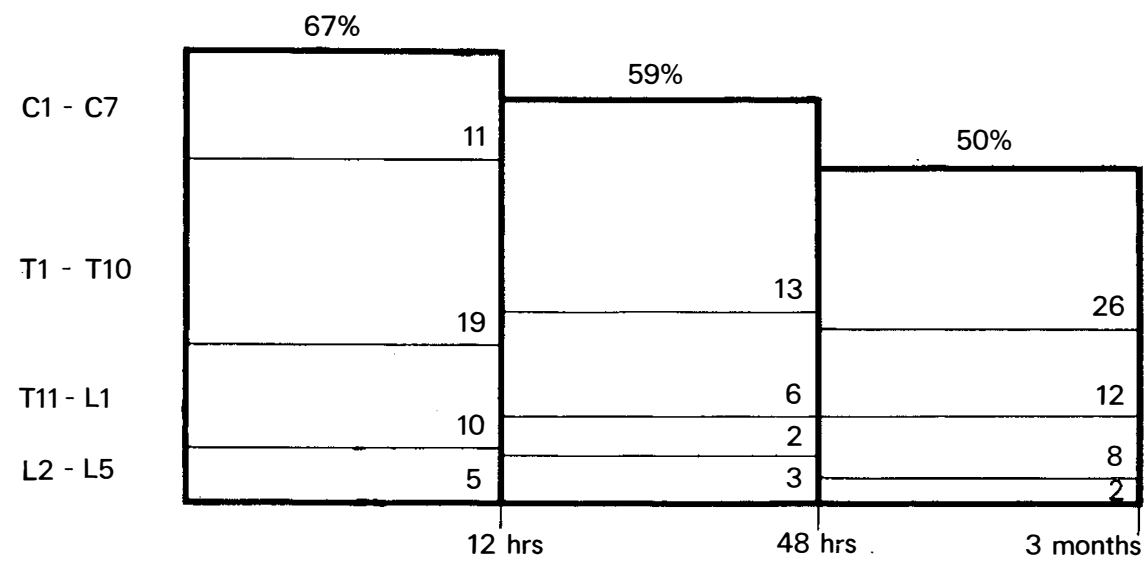

FIG. 3

\section{SUMMARY}

The results concerning the last II 7 acute traumatic spinal cord lesions admitted in the Swiss Paraplegic Centre of Basle have been analysed as regards the rate of neurological recovery. The treatment not only concerns the vertebral damage but also the medical aspects of the spinal cord lesion itself.

The routine use of combined Dexamethasone, Rheomacrodex ${ }^{\circledR}$ and Hydergine ${ }^{\mathbb{R}}$ in the very early treatment might have accounted for encouraging results which need to be confirmed in the future.

\section{RÉSUMÉ}

Cent dix-sept lésions médullaires admis au Centre Suisse des Paraplégiques au cours de la période aiguë post traumatique sont passés en revue en ce qui concerne leur évolution neurologique. En plus du traitement purement orthopédique l'utilisation systématique de la Dexamethasone, du Rheomacrodex $40^{\circledR}$ et de l'Hydergine ${ }^{\circledR}$ en urgence semble avoir donné des résultats encourageants mais qui demandent à être confirmé sur un plus grand nombre de blessés médullaires.

\section{ZUSAMMENFASSUNG}

Eine Analyse der an den letzten II 7 akuten Rückenmarksverletzunger erzielten Resultate in der neurologischen Wierdeharstellungsrate wird gegeben. Die Behandlung betrifft nicht nur den vertebralen Schaden sondern auch die medizinischen Aspekte der Rückenmarkläsion selber. Die kombinierte Routinbehandlung von Dexamethazone, Rheomacrodex ${ }^{\circledR}$ und Hydergine ${ }^{\circledR}$ in akuten Stadium scheint ermutigende Resultate zu haben, die weiterhin bestätigt werden müssen.

\section{REFERENCES}

Campbell, J. B., DeCrescito, V. \& Tomasula, J. J. (1974). Effects of antifibrinolytic and steroid therapy on the contused spinal cords of cats. F. Neurosurg. 40, 726-733.

Dollfus, P., Gschaedler, R., Molé, L. \& Loeb, J.-P. (I97I). Essay de la prévention de la maladie les atteintes médullaires à la période aiguë. Ann. Méd. phys. T.XIV, 4OI-403. 
Dohrmann, J. G., Franklin, Wagner, C. F. \& Bucy, P. C. (I97I). The microvasculature in transitory traumatic paraplegia-An electron microscopic study in the monkey. $\mathcal{F}$. Neurosurg. 35, 263-27I.

Ducker, Th. B. \& HaMit, F. H. (1969). Experimental treatments of acute spinal cord injury. F. Neurosurg. 30, 693-697.

EidelberG, E., Sullivan, J. \& BRIGHAM, A. (I975). Immediate consequences of spinal cord injury: Possible role of potassium in axonal conduction block. Surg. Neurol. 3 , 317-321.

Fairholm, D. J. \& Turnbull, I. M. (I97I). Microangiographic study of experimental spinal cord injuries. F. Neurosurg. 35, 277-286.

Frankel, H. L., Hancock, D. O., Hyslop, G., Melzak, J., Michealis, L. S., Ungar, G. H., VerNon, J. D. S. \& WALSH, J. J. (I969). The value of postural reduction in the initial management of clodes injuries of the spine with paraplegia and tetraplegia. Paraplegia, 7, I79-I92.

FRIED, C. L. \& GOODKIN, R. (I97I). Microangiographic observations of the experimentally traumatized spinal cord. $\mathcal{F}$. Neurosurg. 35, 709-7I4.

Goodman, L. S. \& Gilman, A. (I97I). The Pharmacological Basis of Therapeutics. Ed. MacMillian Comp., U.S.A., p. 786.

Guttmann, L. (1973). Spinal Cord Injuries. Blackwell Scientific Publications.

GuttmanN, L. (I964). Problems in the initial treatment of traumatic paraplegia. Excerpta Medica International Congress Series, Nr. I07, Paris, 6-I I September, 593-596.

HACHEN, H. J. (1974). Anticoagulant therapy in patients with spinal cord injury. Paraplegia, 12, I76-187.

HACHEN, H. J. (1974). Emergency transportation in the event of acute spinal cord lesion. Paraplegia, 12, 33-37.

Hedeman, L. S. \& Sil, R. (1974). Studies in experimental spinal cord trauma. Part 2: Comparison of treatment with steroids, low molecular weight dextran and catecholamine blockade. F. Neurosurg. 40, 44-5I.

Herzefeld, U., Christian, W., OsWald, W. D., Ronge, J. \& Wittgen, M. (I972). Zur Wirkungsanalyse von Hydergin im Langzeitversuch. Med. Klin. 67. fg., 35, I I I8II 25 .

Illingworth, R. D. \& Molina-Negro, P. (I974). Spontaneous and electrically-evoked activity in the anterolateral column of the spinal cord in dogs. $\mathcal{F}$. Neurosurg. 40, 58-64.

Lewin, M. G., Hansebout, R. R. \& Pappius, H. M. (I974). Chemical characteristics of traumatic cord edema in cats. Effect of steroids on potassium depletion. $\mathcal{F}$. Neurosurg. 40, 65-75.

Michaelis, L. S. (1967). Opening of the Swiss Paraplegic Centre of Basle. Paraplegia, 5 , 107.

Osterholm, J. L. (1974). The pathophysiological response to spinal cord injury. $\mathcal{F}$. Neurosurg., 40, 5-33.

Perot, Ph. L. (I973). The clinical use of somatosensory evoked potentials in spinal cord injury. Clin. Neurosurg., Baltimore, 20, 367-381.

Peterson, C. G. \& Haugen, F. P. (I965). Hemorrhagic shock and the nervous system. Ann. Surg. 161, 485-495.

SANDOZ, A. G. (1973). Hydergin ${ }^{\circledR}-$ Neue klinische und klinisch-experimentelle Untersuchungsergebnisse. Mde. Inf. Basel, I-I6.

De la Torre, J. C., Johnson, CH. M., Harris, H. L., Kajihara, K. \& Mullan, S. (1974). Monoamine changes in experimental head and spinal cord trauma: Failure to confirm previous observations. Surg. Neurol. 2, 5-II.

Yeo, J. D., PAYNe, W., Hinwood, B. \& KidMAN, A. D. (1975). The experimental contusion injury of the spinal cord in sheep. Paraplegia, 12, 275-298. 